\title{
Effect of Pre-harvest Sprays of Calcium Compounds and Growth Regulator for Uniform Ripening on Physical Parameters of Sapota Cv. Kalipatti
}

\author{
D. Naga Harshitha*, A. Manohar Rao, A. Girwani, S. Narendar Reddy and Veena Joshi \\ College of Horticulture, Rajendranagar, Hyderabad 500030, Sri Konda Laxman Telangana \\ State Horticultural University, Mulugu, Dist - Siddipet (Telangana), India \\ *Corresponding author
}

\section{A B S T R A C T}

\section{Keywords}

Sapota, Pre-harvest sprays, Gibberellic acid, Calcium chloride, Storage, Shelf-life

\section{Article Info}

Accepted:

20 July 2020

Available Online:

10 August 2020

\begin{abstract}
An experiment was conducted to study the effect of preharvest sprays of calcium compounds and growth regulator on sapota trees at $50 \%$ of the fruit maturity (4 months after fruit set). Various physical parameters like physiological loss in weight, number of days for ripening, firmness, ripening, shelf life, spoilage were estimated. Among these treatments results proved that pre-harvest spray of Gibberellic acid $1000 \mathrm{ppm}\left(\mathrm{T}_{5}\right)$ on sapota exhibited low PLW $(7.34 \%)$ and highest shelf life (12.67 days). Pre-harvest spray of Calcium chloride $2 \%\left(\mathrm{~T}_{2}\right)$ showed maximum firmness $\left(0.26 \mathrm{~kg} / \mathrm{cm}^{2}\right)$, minimum ripening percent $(75.89 \%)$. Pre-harvest spray of Calcium chloride 1\% $\left(\mathrm{T}_{1}\right)$ showed minimum spoilage (58.23 $\%)$, pre-harvest spray of Calcium nitrate $1 \%\left(\mathrm{~T}_{3}\right)$ and Calcium nitrate $2 \%\left(\mathrm{~T}_{4}\right)$ showed highest number of days taken for ripening (9.17 days).
\end{abstract}

\section{Introduction}

Sapota (Manilkara achras (mill) Fosberg) belongs to the family sapotaceae and is native to Mexico in tropical (central) America. Sapota gained popularity in recent decades due to its high productivity, continuous cropping throughout the year, hardy nature, longevity and comparative freedom from pests and diseases. Though sapota cultivation has gained area in the past couple of decades, post harvest problems such as slow and uneven ripening, corky tissue, physiological loss of weight, decay and post harvest losses lead to economic loss to growers, traders, processors and finally consumers. Further ripening in sapota is not uniform (Chundawat, 1998) and it stores poorly at ambient condition. Calcium a secondary essential nutrient is involved in developmental process of fruits, ripening and senescence. Calcium is essential for structural integrity of both the cell wall and plasma membrane. Calcium treatments have known to delay softening and improves the fruit quality. Calcium alters intra cellular changes, firmness, carbon dioxide and ethylene production increase sugar content and decrease acidity in treated fruits. Plant 
growth regulators such as gibberellic acid is extensively used for improving the fruit quality and is found to lead to the uniform ripening and reduction of corky tissue in sapota (Shiva Shankar et al., 2013).

\section{Materials and Methods}

The experiment was carried out at farmer's field in Peddashapur village in Rangareddy district of Telangana and PG lab in College of Horticulture, Rajendranagar during 20162017 and 2017-2018. The experiment was laid out in randomized complete block design with three replications and seven treatments. The sapota trees were sprayed with calcium compounds and growth regulator viz., $\mathrm{T}_{0}$ Control (without spray), $\mathrm{T}_{1}-$ Calcium Chloride $1 \%, \mathrm{~T}_{2}-$ Calcium Chloride $2 \%, \mathrm{~T}_{3}-$ Calcium nitrate $1 \%, \mathrm{~T}_{4}-$ Calcium nitrate $2 \%$, $\mathrm{T}_{5}-$ Gibberellic acid $1000 \mathrm{ppm}, \mathrm{T}_{6}-$ Gibberellic acid 2000 ppm when fruits attained $50 \%$ maturity. The required quantity of $\mathrm{CaCl}_{2}, \mathrm{Ca}\left(\mathrm{No}_{3}\right)_{2}, \mathrm{GA}_{3}$ were weighed and dissolved in 95 percent of alcohol and volume was made up based on the treatments. The fruits were assessed for PLW, Number of days for ripening, firmness, ripening percent, shelf life, spoilage. PLW, firmness and spoilage were assessed at $3^{\text {rd }}, 6^{\text {th }}, 9^{\text {th }}$ and $12^{\text {th }}$ day of storage.

\section{Results and Discussion}

\section{Physiological loss in weight (PLW) (\%)}

The data presented in the Table 1 showed that there was significant difference among treatments in physiological loss in weight during both the years (2016-17, 2017-18) and in pooled data respectively. PLW increased during storage period in all the treatments. In pooled data the lowest physiological loss in weight (\%) was recorded with gibberellic acid $1000 \mathrm{ppm}\left(\mathrm{T}_{5}\right)$ at $3^{\text {rd }}(3.47 \%), 6^{\text {th }}(5.59 \%), 9^{\text {th }}$ $(6.39 \%)$, and $12^{\text {th }}$ day $(7.34 \%)$. Highest PLW
(\%) was noticed with $\mathrm{T}_{0}$ - control on $3^{\text {rd }}(5.17$ $\%), 6^{\text {th }}(7.09 \%), 9^{\text {th }}(9.24 \%)$ days. The possible reason for reduction in weight loss by $\mathrm{GA}_{3}$ could be due to its ability to retain more water against force of evaporation. $\mathrm{GA}_{3}$ acts as an antisenescent and antirespirant, which might have inhibited catabolic activities and consequently reduced the weight loss during storage. These findings are in conformity with the reports of Brahmachari and Rani (2005) in guava, Ladaniya (1997) in Nagpur mandarin. The increased weight loss in untreated fruits might be due to increased storage break down associated with higher respiratory rate compared to treated fruits.

\section{Number of days taken for ripening (days)}

The data on number of days taken for ripening in the Table 2 showed that all the treatments had significant effect on number of days taken for ripening during both the years (2016-17, 2017-18) and in pooled data.

In pooled data significantly highest number of days taken for ripening was recorded with $\mathrm{T}_{3}$ - Calcium nitrate 1\% (9.17 days), $\mathrm{T}_{4}$ Calcium nitrate $2 \%$ (9.17 days) and lowest number of days taken for ripening was noted with $\mathrm{T}_{0}$ - control (7.67 days). The delay of ripening by $\mathrm{CaCl}_{2}$ may be attributed to higher fruit calcium levels that lead to the reduction of respiration and ethylene production rates (Singh et al., 2003).

The delay of ripening by gibberellic acid might be due to reason that the preharvest applications of gibberellic acid decreases the tissue permeability there by reducing the rate of water loss leading to delayed fruit ripening (Wills et al., 1998) and it might have the inhibitory effect on ethylene biosynthesis and retarded the activity of enzymes responsible for ripening through creation of resistance to pathogen entry, hence cell degradation was prevented which in turn facilitated the 
reduced moisture loss and lesser respiratory gas exchange, resulting in delay of ripening.
Similar results were obtained by Mounika et al., (2017) in mango.

Table.1 Effect of preharvest sprays on physiological loss in weight (\%) of sapota cv. Kalipatti

\begin{tabular}{|c|c|c|c|c|c|c|c|c|c|c|c|c|}
\hline \multirow[t]{3}{*}{ Treatments } & \multicolumn{12}{|c|}{ Physiological loss in weight (PLW)(\%) } \\
\hline & \multicolumn{3}{|c|}{$3^{\text {rd }}$ day } & \multicolumn{3}{|c|}{$6^{\text {th }}$ day } & \multicolumn{3}{|c|}{$9^{\text {th }}$ day } & \multicolumn{3}{|c|}{$12^{\text {th }}$ day } \\
\hline & $\begin{array}{l}2016- \\
2017\end{array}$ & $2017-$ & Pooled & $\begin{array}{l}2016- \\
2017\end{array}$ & $2017-$ & Pooled & $\begin{array}{l}2016- \\
2017\end{array}$ & $\begin{array}{l}2017- \\
2018\end{array}$ & Pooled & $\begin{array}{l}2016- \\
2017\end{array}$ & $\begin{array}{l}2017- \\
2018\end{array}$ & Pooled \\
\hline $\begin{array}{l}\mathbf{T}_{0} \text { - Control } \\
\text { (without spray) }\end{array}$ & 5.89 & 4.45 & 5.17 & 7.25 & 6.93 & 7.09 & 9.58 & 8.90 & 9.24 & -- & -- & -- \\
\hline $\begin{array}{l}\mathbf{T}_{1} \text { - Calcium } \\
\text { Chloride 1\% }\end{array}$ & 3.57 & 3.55 & 3.56 & 5.72 & 5.56 & 5.64 & 6.60 & 6.36 & 6.48 & 7.41 & -- & -- \\
\hline $\begin{array}{l}\mathbf{T}_{2} \text { - Calcium } \\
\text { Chloride 2\% }\end{array}$ & 3.87 & 3.62 & 3.75 & 6.10 & 5.79 & 5.95 & 6.58 & 6.44 & 6.51 & 8.36 & -- & -- \\
\hline $\begin{array}{l}T_{3}-\text { Calcium } \\
\text { nitrate } 1 \%\end{array}$ & 4.19 & 4.08 & 4.14 & 6.73 & 6.45 & 6.59 & 7.42 & 7.34 & 7.38 & -- & -- & -- \\
\hline $\begin{array}{l}\mathrm{T}_{4}-\text { Calcium } \\
\text { nitrate } 2 \%\end{array}$ & 4.40 & 4.24 & 4.32 & 6.87 & 6.61 & 6.74 & 7.14 & 7.04 & 7.09 & -- & -- & -- \\
\hline $\begin{array}{l}T_{5} \text { - Gibberellic } \\
\text { acid } 1000 \mathrm{ppm}\end{array}$ & 3.49 & 3.44 & 3.47 & 5.84 & 5.32 & 5.59 & 6.44 & 6.34 & 6.39 & 7.40 & 7.27 & 7.34 \\
\hline $\begin{array}{l}T_{6} \text { - Gibberellic } \\
\text { acid } 2000 \mathrm{ppm}\end{array}$ & 3.76 & 3.52 & 3.64 & 5.89 & 5.38 & 5.64 & 6.66 & 6.46 & 6.56 & -- & -- & -- \\
\hline Mean & 4.17 & 3.84 & 4.00 & 6.34 & 6.00 & 6.17 & 7.20 & 6.98 & 7.09 & & & \\
\hline SE.m. \pm & 0.10 & 0.02 & 0.05 & 0.10 & 0.01 & 0.05 & 0.03 & 0.01 & 0.02 & & & \\
\hline CD at $5 \%$ & 0.30 & 0.06 & 0.16 & 0.30 & 0.03 & 0.14 & 0.10 & 0.03 & 0.06 & & & \\
\hline
\end{tabular}

‘-' Fruits spoiled

Table.2 Effect of preharvest sprays on number of days for ripening (days) of sapota cv. Kalipatti

\begin{tabular}{|c|c|c|c|}
\hline \multirow[t]{2}{*}{ Treatments } & \multicolumn{3}{|c|}{ Number of days for ripening (days) } \\
\hline & 2016-2017 & 2017-2018 & Pooled \\
\hline $\mathbf{T}_{0^{-}}$Control (without spray) & 8.00 & 7.33 & 7.67 \\
\hline $\mathrm{T}_{1}$ - Calcium Chloride 1\% & 8.00 & 8.67 & 8.33 \\
\hline $\mathrm{T}_{2}$ - Calcium Chloride $2 \%$ & 8.67 & 9.00 & 8.83 \\
\hline $\mathrm{T}_{3}$ - Calcium nitrate $1 \%$ & 9.00 & 9.33 & 9.17 \\
\hline $\mathrm{T}_{4}$ - Calcium nitrate $2 \%$ & 9.33 & 9.00 & 9.17 \\
\hline$T_{5}$ - Gibberellic acid 1000 ppm & 8.33 & 8.00 & 8.17 \\
\hline$T_{6}-$ Gibberellic acid $2000 \mathrm{ppm}$ & 8.67 & 8.33 & 8.50 \\
\hline Mean & 8.57 & 8.52 & 8.55 \\
\hline SE.m. \pm & 0.21 & 0.36 & 0.22 \\
\hline CD at $5 \%$ & 0.64 & 1.11 & 0.68 \\
\hline
\end{tabular}


Table.3 Effect of preharvest sprays on fruit firmness $\left(\mathrm{kg} / \mathrm{cm}^{2}\right)$ of sapota cv. Kalipatti

\begin{tabular}{|c|c|c|c|c|c|c|c|c|c|c|c|c|}
\hline \multirow{3}{*}{ Treatments } & \multicolumn{12}{|c|}{ Fruit firmness $\left(\mathrm{kg} / \mathrm{cm}^{2}\right)$} \\
\hline & \multicolumn{3}{|c|}{$3^{\text {rd }}$ day } & \multicolumn{3}{|c|}{$6^{\text {th }}$ day } & \multicolumn{3}{|c|}{$9^{\text {th }}$ day } & \multicolumn{3}{|c|}{$12^{\text {th }}$ day } \\
\hline & $\begin{array}{l}2016- \\
2017\end{array}$ & $\begin{array}{l}2017- \\
2018\end{array}$ & Pooled & $\begin{array}{l}2016- \\
2017\end{array}$ & $\begin{array}{l}2017= \\
2018\end{array}$ & Pooled & $\begin{array}{l}2016- \\
2017\end{array}$ & $\begin{array}{l}2017- \\
2018\end{array}$ & Pooled & $\begin{array}{l}2016- \\
2017\end{array}$ & $\begin{array}{l}2017- \\
2018\end{array}$ & Pooled \\
\hline $\begin{array}{l}\mathbf{T}_{0^{-}} \text {Control } \\
\text { (without spray) }\end{array}$ & 7.22 & 6.17 & 6.69 & 5.17 & 4.12 & 4.65 & 2.03 & 2.05 & 2.04 & -- & -- & -- \\
\hline $\mathbf{T}_{1-}$ Calcium Chloride $1 \%$ & 7.37 & 6.23 & 6.80 & 5.29 & 4.20 & 4.75 & 2.11 & 2.13 & 2.12 & 0.26 & -- & -- \\
\hline $\mathrm{T}_{2^{-}}$Calcium Chloride $2 \%$ & 7.35 & 6.24 & 6.80 & 5.51 & 4.24 & 4.88 & 2.17 & 2.15 & 2.16 & 0.28 & 0.27 & 0.26 \\
\hline $\mathrm{T}_{3}-$ Calcium nitrate $1 \%$ & 7.35 & 6.23 & 6.79 & 5.27 & 4.20 & 4.73 & 2.11 & 2.13 & 2.12 & -- & -- & -- \\
\hline $\mathrm{T}_{4}$ - Calcium nitrate $2 \%$ & 7.32 & 6.19 & 6.76 & 5.18 & 4.21 & 4.70 & 2.11 & 2.14 & 2.13 & -- & -- & -- \\
\hline$T_{5}-$ Gibberellic acid 1000 ppm & 7.28 & 6.25 & 6.77 & 5.37 & 4.33 & 4.85 & 2.09 & 2.15 & 2.12 & 0.21 & -- & -- \\
\hline $\mathrm{T}_{6}$ - Gibberellic acid 2000 ppm & 7.27 & 6.22 & 6.74 & 5.36 & 4.23 & 4.80 & 2.16 & 2.14 & 2.15 & -- & -- & -- \\
\hline Mean & 7.31 & 6.20 & 6.76 & 5.31 & 4.22 & 4.76 & 2.11 & 2.13 & 2.12 & & & \\
\hline SE.m. \pm & 0.02 & 0.01 & 0.01 & 0.03 & 0.01 & 0.05 & 0.01 & 0.01 & 0.01 & & & \\
\hline CD at $5 \%$ & 0.07 & 0.03 & 0.04 & 0.09 & 0.03 & 0.15 & 0.04 & 0.04 & 0.04 & & & \\
\hline
\end{tabular}

'-'Fruits spoiled

Table.4 Effect of preharvest sprays on ripening (\%) of sapota cv. Kalipatti

\begin{tabular}{|c|c|c|c|}
\hline \multirow[t]{2}{*}{ Treatments } & \multicolumn{3}{|c|}{ Ripening (\%) } \\
\hline & 2016-2017 & 2017-2018 & Pooled \\
\hline $\mathbf{T}_{0^{-}}$Control (without spray) & 86.67 & 76.50 & 81.58 \\
\hline $\mathrm{T}_{1-}$ - Calcium Chloride 1\% & 82.70 & 76.35 & 79.53 \\
\hline $\mathbf{T}_{2-}$ - Calcium Chloride $2 \%$ & 80.33 & 71.44 & 75.89 \\
\hline $\mathrm{T}_{3}$ - Calcium nitrate $1 \%$ & 82.51 & 74.44 & 78.47 \\
\hline $\mathbf{T}_{4}$ - Calcium nitrate $2 \%$ & 81.45 & 71.64 & 76.55 \\
\hline$T_{5}$ - Gibberellic acid 1000 ppm & 84.00 & 76.16 & 80.08 \\
\hline$T_{6}-$ Gibberellic acid 2000 ppm & 82.68 & 75.33 & 79.01 \\
\hline Mean & 82.91 & 74.55 & 78.73 \\
\hline SE.m. \pm & 0.42 & 0.14 & 0.20 \\
\hline CD at $5 \%$ & 1.31 & 0.45 & 0.63 \\
\hline
\end{tabular}


Table.5 Effect of preharvest sprays on shelf life (days) of sapota cv. Kalipatti

\begin{tabular}{|c|c|c|c|}
\hline \multirow[t]{2}{*}{ Treatments } & \multicolumn{3}{|c|}{ Shelf life (days) } \\
\hline & 2016-2017 & 2017-2018 & Pooled \\
\hline $\mathbf{T}_{0}$ - Control (without spray) & 10.33 & 8.67 & 9.50 \\
\hline $\mathrm{T}_{1}$ - Calcium Chloride $1 \%$ & 11.67 & 10.67 & 11.17 \\
\hline $\mathrm{T}_{2}$ - Calcium Chloride $2 \%$ & 12.67 & 11.33 & 12.00 \\
\hline$T_{3}$ - Calcium nitrate $1 \%$ & 12.00 & 10.67 & 11.33 \\
\hline $\mathrm{T}_{4}$ - Calcium nitrate $2 \%$ & 11.33 & 10.00 & 10.67 \\
\hline $\mathrm{T}_{5}$ - Gibberellic acid 1000 ppm & 13.00 & 12.33 & 12.67 \\
\hline $\mathrm{T}_{6}-$ Gibberellic acid 2000 ppm & 12.00 & 11.67 & 11.83 \\
\hline Mean & 11.86 & 10.76 & 11.31 \\
\hline SE.m. \pm & 0.27 & 0.30 & 0.18 \\
\hline CD at $5 \%$ & 0.85 & 0.95 & 0.56 \\
\hline
\end{tabular}

Table.6 Effect of preharvest sprays on spoilage (\%) of sapota cv. Kalipatti

\begin{tabular}{|c|c|c|c|c|c|c|c|c|c|c|c|c|}
\hline \multirow[t]{3}{*}{ Treatments } & \multicolumn{12}{|c|}{ Spoilage (\%) } \\
\hline & \multicolumn{3}{|c|}{$3^{\text {rd }}$ day } & \multicolumn{3}{|c|}{$6^{\text {th }}$ day } & \multicolumn{3}{|c|}{$9^{\text {th }}$ day } & \multicolumn{3}{|c|}{$12^{\text {th }}$ day } \\
\hline & $\begin{array}{l}\text { 2016- } \\
2017\end{array}$ & $\begin{array}{l}2017- \\
2018\end{array}$ & Pooled & $\begin{array}{l}\text { 2016- } \\
2017\end{array}$ & $\begin{array}{l}2017- \\
2018\end{array}$ & Pooled & $\begin{array}{l}2016- \\
2017\end{array}$ & $\begin{array}{l}2017- \\
2018\end{array}$ & Pooled & $\begin{array}{l}2016- \\
2017\end{array}$ & $\begin{array}{l}2017- \\
2018\end{array}$ & Pooled \\
\hline $\begin{array}{l}\mathbf{T}_{0} \text { - Control } \\
\text { (without spray) }\end{array}$ & 10.30 & 9.30 & 9.80 & 25.55 & 24.49 & 25.02 & 63.64 & 51.64 & 57.64 & -- & -- & -- \\
\hline $\begin{array}{l}T_{1-} \text { Calcium } \\
\text { Chloride } 1 \%\end{array}$ & 1.21 & 3.37 & 2.29 & 15.51 & 12.37 & 13.94 & 26.33 & 19.33 & 22.83 & 54.33 & 56.23 & 58.23 \\
\hline $\begin{array}{l}T_{2-} \text { Calcium } \\
\text { Chloride } 2 \%\end{array}$ & 1.21 & 4.42 & 2.81 & 20.42 & 15.34 & 17.88 & 47.23 & 42.33 & 44.78 & 62.34 & -- & --- \\
\hline $\begin{array}{l}T_{3}-\text { Calcium } \\
\text { nitrate } 1 \%\end{array}$ & 1.23 & 5.51 & 3.37 & 15.56 & 12.55 & 14.06 & 31.50 & 27.32 & 29.41 & -- & -- & -- \\
\hline $\begin{array}{l}\mathrm{T}_{4}-\text { Calcium } \\
\text { nitrate } 2 \%\end{array}$ & 1.22 & 6.59 & 3.91 & 21.38 & 17.35 & 19.36 & 40.50 & 35.37 & 37.94 & -- & -- & -- \\
\hline $\begin{array}{l}T_{5}-\text { Gibberellic } \\
\text { acid } 1000 \text { ppm }\end{array}$ & 1.13 & 4.14 & 2.64 & 14.11 & 11.09 & 12.60 & 30.26 & 24.27 & 27.27 & 60.23 & -- & -- \\
\hline $\begin{array}{l}T_{6}-\text { Gibberellic } \\
\text { acid } 2000 \text { ppm }\end{array}$ & 1.13 & 4.41 & 2.77 & 15.29 & 12.29 & 13.79 & 32.41 & 28.41 & 30.41 & -- & -- & -- \\
\hline Mean & 2.49 & 5.39 & 3.94 & 18.26 & 15.07 & 16.66 & 38.84 & 32.67 & 35.75 & & & \\
\hline SE.m. \pm & 0.07 & 0.08 & 0.07 & 0.13 & 0.10 & 0.11 & 0.33 & 0.28 & 0.10 & & & \\
\hline CD at $5 \%$ & 0.20 & 0.24 & 0.22 & 0.41 & 0.31 & 0.35 & 1.02 & 0.86 & 0.31 & & & \\
\hline
\end{tabular}




\section{Firmness $\left(\mathrm{kg} / \mathrm{cm}^{2}\right)$}

The data pertaining to fruit firmness in the Table 3 showed that fruit firmness gradually decreased during storage period, due to advancement of ripening, senescence and break down in the later stage during both the years $(2016-17,2017-18)$ and in pooled data. In pooled data significantly highest fruit firmness was recorded with $\mathrm{T}_{2}$ - Calcium Chloride $2 \%$ on $3^{\text {th }}\left(6.80 \mathrm{~kg} / \mathrm{cm}^{2}\right), 6^{\text {th }}(4.88$ $\left.\mathrm{kg} / \mathrm{cm}^{2}\right), 9^{\text {th }}\left(2.16 \mathrm{~kg} / \mathrm{cm}^{2}\right)$ and $12^{\text {th }}$ day $\left(0.26 \mathrm{~kg} / \mathrm{cm}^{2}\right)$. This might be due to the application of calcium which helped to maintain the structure and function of cell wall. It was observed that fruits having higher concentration of calcium compound in preharvest sprays retained higher firmness. This was probably due to the more calcium content in peel and pulp which helped to maintain the structure and function of cell wall. Calcium made the complex with pectin and formed calcium pectate and thereby increased the firmness of the fruits. Similar result was also obtained by Lakshmana and Reddy (1999), Aradhya et al., (2006) and Desai (2016) in sapota, Rajkumar et al., (2006) in papaya.

\section{Ripening Percentage (\%)}

The data depicted in Table.4 regarding ripening percentage (\%) of sapota Cv. Kalipatti as effected by different treatments showed significant difference during both the years $(2016-17,2017-18)$ and in pooled data. In pooled data significantly highest ripening percent was observed with $\mathrm{T}_{0}$ - Control (81.58 $\%$ ) followed by $\mathrm{T}_{5}$ - Gibberellic acid 1000 ppm $(80.08 \%)$. Lowest ripening percent was recorded with $\mathrm{T}_{2}$ - Calcium Chloride 2\% $(75.89 \%)$. The ripening percentage increased with advancement of storage period. Ripening was closely associated with climacteric peak in all the treatments including control. Highest ripening percent was noted with control and lowest was recorded with calcium compounds. This might be due to extension of ripening period by calcium compounds as $\mathrm{Ca}^{2+}$ ion alters intracellular and intercellular biological activity, resulting in retardation of ripening. Similar results were obtained by Virendra Singh et al., (2017) in mango.

\section{Shelf life (days)}

The data pertaining to shelf life (days) of sapota Cv. Kalipatti as influenced by different treatments presented in Table 5 showed that treatments varied significantly during both the years $(2016-17,2017-18)$ and in pooled data. In pooled data significantly highest shelf life was found in $\mathrm{T}_{5}-$ Gibberellic acid $1000 \mathrm{ppm}$ (12.67 days) followed by $\mathrm{T}_{2}$ - Calcium Chloride 2\% (12.00 days) and lowest shelf life was recorded with the treatment $\mathrm{T}_{0}$ control (9.50 days). The extension of shelf life of fruits by the application of $\mathrm{GA}_{3}$ might be due to the reduced oxidative metabolism and pectin break down through reduced catalase and pectin methyl esterase activities (Gautam and Chundawat, 1990). The extended shelf life in $\mathrm{CaCl}_{2}$ treatment may be due to the fact that calcium enhances fruit firmness relative to control which leads to slower hastening and extends the shelf-life. Similar results were obtained by Marzouk and Kassim (2011) in Navel orange, Mounika et al., (2017) in mango.

\section{Spoilage (\%)}

The data presented in Table 6 showed that treatments varied significantly in spoilage during both the years $(2016-17,2017-18)$ and in pooled data. In pooled data lowest spoilage was recorded with $\mathrm{T}_{1}$ - Calcium Chloride $1 \%$ on $3^{\text {th }}(2.29 \%), 9^{\text {th }}(22.83 \%)$ and $12^{\text {th }}(58.23$ $\%)$ days. Highest spoilage was recorded with control. This might be due to the reason that calcium chloride showed less spoilage which might be due to decreased rate of respiration resulting in to control of enzymatic activities, 
ethylene production and senescence, better fruit firmness and calcium content in peel, ultimately resulted in stronger intracellular organization and rigidified cell wall. Similar reduction on fruit rot during storage with calcium compound has been reported by Bhale Rao et al., (2009) in sapota, Lakshmana and Reddy (1999) and Aradhya et al., (2006), Saran et al., (2004) in ber.

In conclusion on the basis of findings, it can be concluded that preharvest spraying of $\mathrm{CaCl}_{2} @ 1 \%$ found better for reducing spoilage and Gibberellic acid 1000 ppm $\left(\mathrm{T}_{5}\right)$ was found better for increasing shelf life and reducing physiological loss in weight of sapota fruits.

\section{References}

Aradhya, S. M and Police gourd, R. S. 2006. Pre and Post-harvest technology of Sapota. Indian Food packer. 60(1): 6371.

Bhalerao, R. R., B. R. Parmar, B. V. Padhiar and Bhalerao, P. P. 2007. Preharvest spray of different sources of calcium to improve the physiological qualities of sapota fruits [Manilkara achras (Mill.) Forsberg] Cv. Kalipatti. Asian Sciences. 4(1-2): 53-55.

Brahmachari, V. S., and Rani, R. 2005. Shelf Life extension in guava with preharvest spray of certain growth substances and polyethylene Wrapping. Haryana Journal of Horticulture Science. 34: 3638 .

Chundawat, B. S., 1998. Sapota. Agrotech Publishing Academy, Udaipur, India.

Desai, V. N., 2016. Influence of pre harvest spraying treatment of chemicals and plant growth regulators on quality parameters and shelf life of Sapota (Manilkara achrus (Mill.) Fosberg) fruits Cv. Kalipatti. M.Sc. Thesis, Anand Agricultural University, Anand,
Gujarat, India.

Gautam, S. K. and Chundawat, B. S., 1990. Post-harvest changes in sapota $\mathrm{Cv}$. 'Kalipatti': II-Effect of various postharvest treatments on physico-chemical attributes. Indian Journal of Horticulture. 47 (3): 264-69.

Ladaniya, M. S., 1997. Response of Nagpur mandarin fruit to preharvest sprays of $\mathrm{GA}_{3}$ and carbendazim. Indian Journal of Horticulture. 54: 205-212.

Lakshmana \& Reddy T, V. Effect of Pre harvest foliar application of Calcium on the post harvest behavior of Sapota (Cv. Kalipatti) fruits. South Indian Horticulture. 47(1-6): 147-148.

Marzouk, H. A., and Kassem, H. A. 2011. Extending harvest season and enhancing shelf life of navel oranges by preharvest treatments with different bioregulators. American Eurasian Journal of Agricultural and Environmental Sciences. 10(3): 396403.

Mounika, T., N.N. Reddy and N, N. Jyothi Lakshmi \& Veena Joshi, 2017. Effect of pre harvest treatments on shelf life and quality of mango Cv. Amrapali. The Pharma Innovation Journal. 6(7): 54-59.

Rajkumar, M., P. Karuppaiah and Andasamy, R. K., 2006. Effect of preharvest application of calcium on storage behaviour, ripening and shelf life of papaya (Carica papaya L.). International Journal of Agriculture Sciences. 2(2): 480-482.

Saran, P. L., G. Lal, R. J. Zat, and Singh, R. V., 2004. Effect of pre harvest foliar application of different chemicals on shelf life and quality of ber (Zizyphus mauritiana Lamk) Cv. Gola. Haryana Journal of Horticulture Science. 33(12): 71-73.

Shiva Shankar, S., J. Joshi, and Sumathi, M., 2013. The role of seed development of 
Corky tissue in Sapota fruit. Journal of Horticultural Science and Biotechnology. 82: 35-40.

Singh, B. P., B.K. Pandey and Jacob, S., 2003. Effect of pre-harvest spray of fungicide, calcium compound and postharvest treatments on storage behavior of mango, National Seminar on Mango, GAU, Junagadh. 14-15: 88.

Virendra Singh, G., D.K. Pandey, R.A. Sarolia, Kaushik and Gora, J. S., 2017. Influence of Pre Harvest Application of
Calcium on Shelf Life and Fruit Quality of Mango (Mangifera indica L.) Cultivars. Int. J. Curr. Microbiol. App. Sci. 6(4): 1366-1372.

Wills, R. B., D. Mc Glasson. D. Joyce, 1998. Post Harvest: An Introduction to the physiology and handling of fruit, vegetables and ornamentals $4^{\text {th }}$ edition, $\mathrm{CAB}$ International, Wallingford. 108:262.

\section{How to cite this article:}

Naga Harshitha, D., A. Manohar Rao, A. Girwani, S. Narendar Reddy and Veena Joshi. 2020. Effect of Pre-harvest Sprays of Calcium Compounds and Growth Regulator for Uniform Ripening on Physical Parameters of Sapota Cv. Kalipatti. Int.J.Curr.Microbiol.App.Sci. 9(08): 2069-2076. doi: https://doi.org/10.20546/ijcmas.2020.908.234 